\title{
Studi Katalitik Herbal Pemanfaatan Tanaman Brotowali (Tinospora Cordifolia) sebagai Obat Penurun Kadar Glukosa Darah (Diabetes Mellitus)
}

\author{
Alivia Maylina*1 \\ ${ }^{1}$ Pendidikan Kimia, FMIPA, Universitas Negeri Padang, \\ Indonesia \\ *E-mail: maylinavia97@gmail.com
}

\begin{abstract}
Abstrak : Studi ini bertujuan untuk membuat ekstrak tanaman brotowali untuk penurun kadar glukosa darah (Diabetes Mellitus) dalam tubuh. Metode yang dilakukan adalah eksperimen dan uji katalitik secara langsung. Bagian tanaman yang diambil adalah batangnya dengan uji aktivitas langsung dilakukan dengan bervariasi seperti direbus, dan diminum secara langsung selama 7 hari. Tahapan pertama dilakukkan dengan ekstrak dari batang tanaman brotowali. Hasil eksperimen membuktikan bahwa pada ekstrak batang tanaman brotowali dapat menurunkan kadar glukosa darah (Diabetes Mellitus) dalam tubuh. Penyembuhan ini diduga karena adanya aktivitas katalitik ekstrak batang tanaman brotowali terhadap tubuh sehingga ekstrak daun dan batang tanaman brotowali dapat menurunkan kadar glukosa (Diabetes Mellitus).
\end{abstract}

Kata kunci : Tanaman Brotowali, Katalitik, Gula Darah

\section{Pendahuluan}

Reaksi kimia adalah reaksi yang terjadi perubahan dari zat semula yang menghasilkan produk baru yang memiliki sifat yang berbeda ${ }^{[1-5]}$. Reaksi kimia sendiri banyak kita jumpai dalam kehidupan sehari-hari ${ }^{[6]}$. Zat-zat yang juga dengan reaktan atau peraksi ${ }^{[7-10]}$. Didalam tubuh manusia sendiri banyak terjadinya reaksi kimia ${ }^{[11-13]}$. Reaksi kimiadapat terjadi dimana pun.

Reaksi kimia dapat berjalan lambat atau cepat akibat adanya bantuan dari katalis. Dimana katalis ${ }^{[14-17]}$ sendiri terjadi pada reaksi kimia yaitu membantu mempercepat terjadinya reaksi yang dapat kita jumpai pada tumbuhan maupun bahan kimia ${ }^{[18-21]}$. Dari segi kesehatan katalis berfungsi meningkatkan sistem kekebalantubuh serta meningkatnya antioksidan dalam tubuh $^{[22-23]}$.

Tanaman Brotowali adalah jenis tumbuhan yang banyak ditemukan disekitar kita. Brotowali sendiri merupakan tanaman obat tradisional Indonesia yang biasa di tanam di perkarangan rumah, diladang dan tanaman ini juga tumbuh liar di hutan ${ }^{[24-28]}$. Tanaman Brotowali sendiri sangat menyukai tempat terbuka yang terkena sinar matahari langsung sehingga 
dapat tumbuh di daerah hutan atau semak belukar didaerah tropis seperti di Indonesia $^{\text {[29-34] }}$.

Pemanfaatan tanaman Brotowali sendiri banyak terdapat pada bagian daun dan batangnya karena pada bagian ini mengandung flavonoid, alkaloid, saponin, dan tannin ${ }^{[35-39]}$. Bagian batang Brotowali sendiri dimanfaatkan untuk penyakit rematik, demam, sakit kuning, batuk, dan cacingan. Daun Brotowali dimanfaatkan untuk mencuci luka pada kulit atau pada bagian gatal-gatal. Sedangkan pada air rebusan batang Brotowali banyak digunakan untuk penurun kadar glukosa darah ${ }^{[40-43]}$ atau disebut juga penyakit kencing manis (Diabetes Mellitus).

Tanaman Brotowali merupakan tanaman obat alami yang seluruh bagian miliki manfaat bagi tubuh ${ }^{[44-50]}$. Akan tetapi pada bagian akarnya disarankan untuk tidak menggunakannya karena pada bagian ini mengandung senyawa berberin yang mana memiliki efek samping seperti sesak napas, lesu, mimisan, iritasi pada kulit, diare, muntah dan bias menyebabkan keracunan yang mematikan ${ }^{[51-55]}$.

Diabetes Mellitus (DM) merupakan salah satu penyakit yang serius bagi kesehatan masyarakat dimana pada penderita diabetes tidak dapat menghasilkan insulin dalam tubuh sehingga terjadi kelebihan kadar gula dalam tubuh ${ }^{[56-60]}$. Penyakit (DM) terjadi akibat pola makan yang tidak teratur baik segi jumlah, jadwal maupun jenis makan yang dikonsumsi ${ }^{[61-65]}$.

Vitamin $\mathrm{C}$ sendiri sangat dibutuhkan oleh penderita diabetes dimana vitamin $\mathrm{C}$ memiliki fungsi sebagai antioksidan yaitu mencegah berkembangnya diabetes pada penderita ${ }^{[66-70]}$. Selain itu Vitamin C sebagai antioksidan akan memberikan manfaat dalam memperkuat enzim pertahanan dan menurunkan peroksidasi lipid ${ }^{[71-75]}$. Semakin banyak asupan vitamin C makan semakin turun kadar glukosa ${ }^{[76-80]}$.

Dari informasi yang didapat mengenai ekstrak daun dan batang Tanaman Brotowali yang dapat membantu menurunkan kadar gula darah (Diabetes Mellitus) jadi memacu praktikan untuk menguji pengaruh ekstrak daun dan batang Tanaman Brotowali terhadap penurunan kadar glukosa darah (Diabetes Mellitus ${ }^{\text {[81-85] }}$. Penelitian sendiri bertujuan untuk membuktikan apakah ekstrak daun dan batang Tanaman Brotowali dapat menurunkan kadar glukosa darah (Diabetes Mellitus ${ }^{[86-90]}$.

\section{Metode}

\section{Alat dan Bahan}

Peralatan yang digunakan adalah Pisau (Yatama), Gelas (Tupperware), Sendok (Stainlesssteal), Panci (Buterflay).

Bahan yang digunakan adalah Tanaman Brotowali yang diambil dari daerah Jl. Gurun Laweh No.54 Kota Padang, Air (Aqua).

\section{Prosedur Kerja}

\section{Penyiapan sampel}

Sampel diambil dari daerah J1. Gurun Laweh No.54 Kota Padang sebanyak 2 batang Brotowali. Kemudian sampel bersihkan dengan air. 


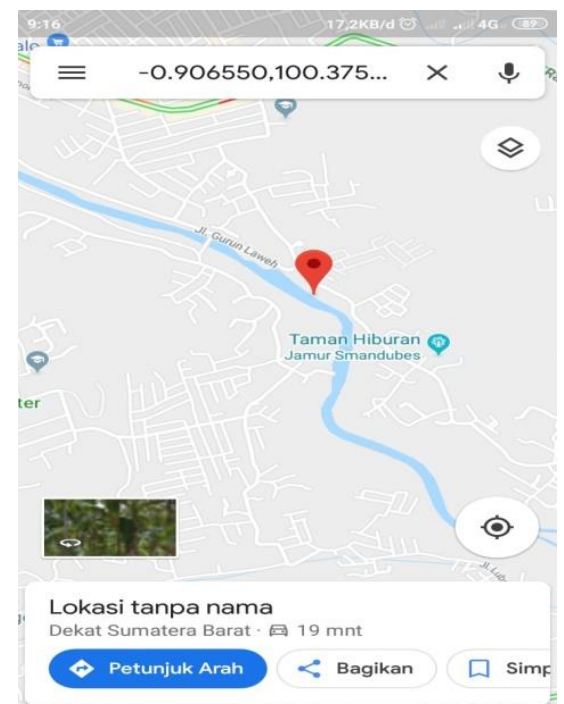

Gambar 1. Denah lokasi pengambilan sampel Tanaman Brotowali

2. Pembuatan air rebusan

Ekstrak dibuat dengan cara memotong sebanyak 2 batang Brotowali ukuran $20 \mathrm{~cm}$, lalu menggeprek serta menambahkan air (aqua) 2 gelas. Kemudian direbus hingga air mendidih dan berubah warna. Lalu masukkan ke dalam gelas.

\section{Pengujian air rebusan}

Ekstrak yang telah jadi kemudian dicobakan ke penderita Diabetes Mellitus dengan varian satu kali sehari selama tujuh hari. Hasil yang didapat ketika meminum selama tujuh hari didapatkan penurunan kadar gula darah.

Metode ini dibuat dalam diagram alir yaitu sebagai berikut :

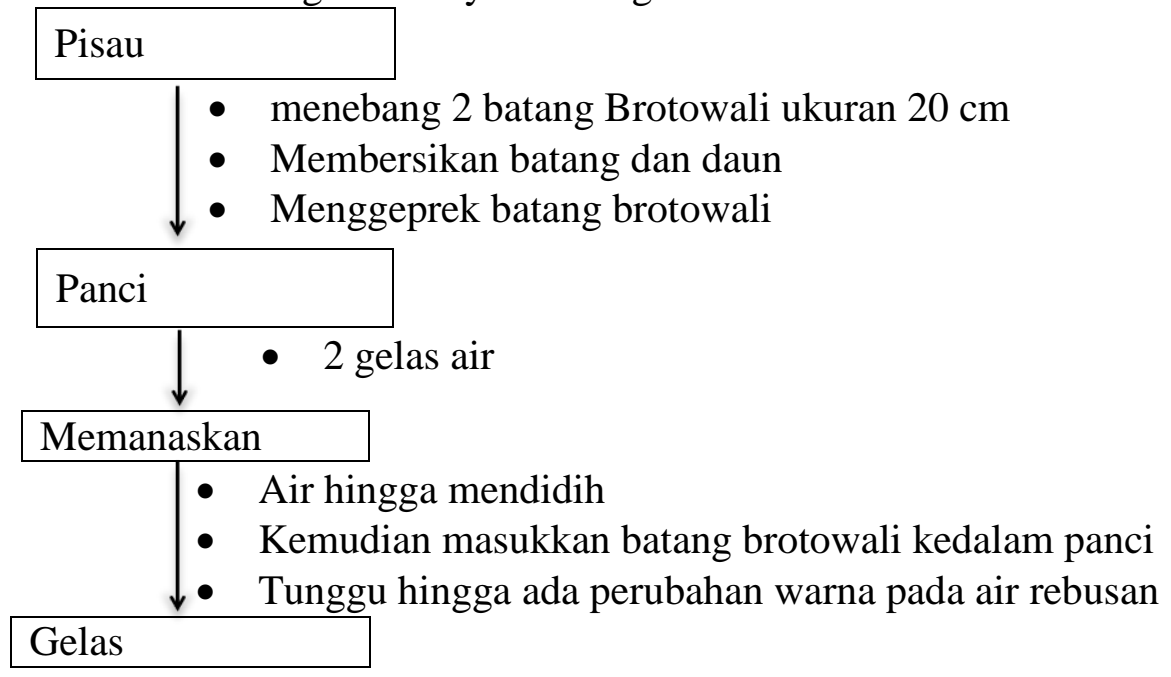


- Setelah didapatkan segelas ekstrak

- Sajikan dalam gelas

Siap untuk diminum

\section{Hasil dan Pembahasan Hasil}

\section{Hasil Pembuatan}

Hasil pembuatan ekstrak diperoleh sebanyak satu gelas. Pembuatan dari 2 batang Brotowali ukuran $20 \mathrm{~cm}$ dengan dua gelas air menghasilkan satu gelas ekstrak. Hal ini dapt dilihat dari gambar berikut ini:

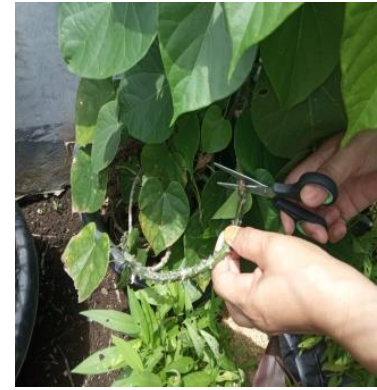

(a)

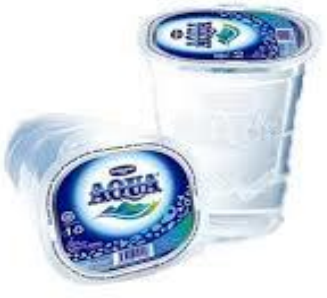

(b)

Gambar 2. Sampel dan bahan yang digunakan (a). Daun dan batang Brotowali diambil dari daerah Jl. Gurun Laweh No.54 Kota Padang, (b). Air mineral gelas

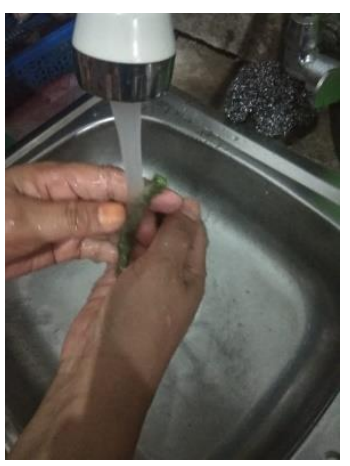

(a)

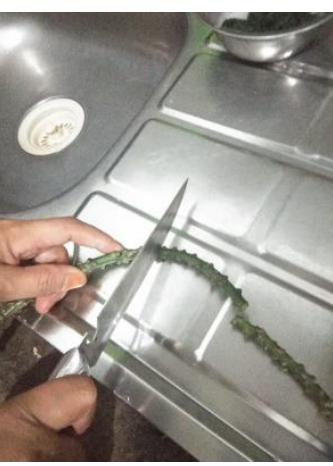

(b) 


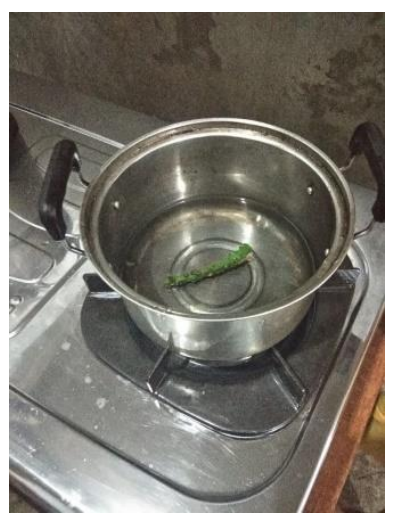

(c)

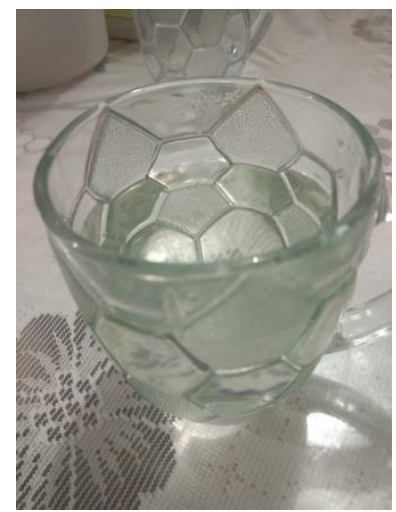

(d)

Gambar 3. Proses pembuatan rebusan (a) Sampel dipotong (b) sampel dibersihkan, (c) Kemudian sampel direbus menggunakan 2 gelas air sampai menyisakan satu gelas saja, (d) Hasil rebusan batang Brotowali

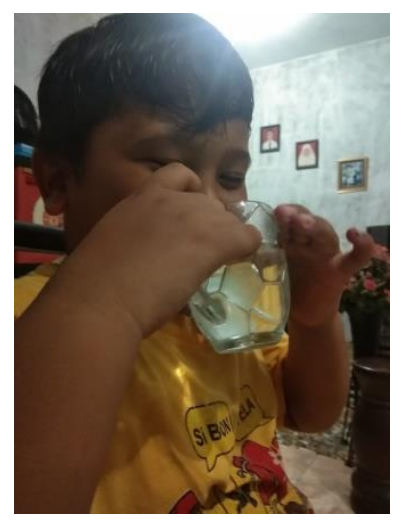

Gambar 4. Mencobakan kepada penderita hasil dari ekstrak batang brotowali untuk membuktikannya

\section{Hasil uji coba}

Pengujian sendiri dilakukan terhadap orang yang memiliki penyakit Diabetes Mellitus ternyata dapat menurukan kadar glukosa dalam darah, dapat dilihat pada tabel berikut :

Tabel 1. Hasil Pengamatan Pada Pemakaian Ekstrak

\begin{tabular}{ccc}
\hline Hari Ke & $\begin{array}{c}\text { Jumlah penggunaan } \\
(\mathbf{m l})\end{array}$ & $\begin{array}{c}\text { Kadar glukosa darah } \\
(\mathbf{m g} / \mathbf{d L})\end{array}$ \\
\hline 1 & 30 & 195 \\
2 & 35 & 180 \\
3 & 45 & 170 \\
4 & 50 & 160 \\
5 & 60 & 150
\end{tabular}




\begin{tabular}{lll}
\hline 6 & 65 & 145 \\
7 & 75 & 140 \\
\hline
\end{tabular}

\section{PEMBAHASAN}

1. Pembuatan

Ketika pembuatan ekstrak batang Brotowali terdapat kendala yaitu mencari tanamannya, dimana tanaman sidikit sulit di temukan ${ }^{[92-98]}$. Tanaman sendiri didapatkan lumayan jauh dari lokasi penelitian. Kemudian ketika pemanasan terjadi kendala yaitu panas terlalu besar sehingga pemanasannya terlalu cepat. Proses pemanasan nya harus diamati dengan seksama, bertujuan untuk mengetahui air rebusan bias jadi air didalam panci sudah kering.

Dalam melakukan penelitian sampel didapat dari daerah Jl. Gurun Laweh No.54 Kota Padang. Tanaman Brotowali (Tinospora Cordifolia) merupakan tanaman yang banyak tersebar di seluruh Indonesia khususnya didaerah tropis. Dalam mengkonsumsi C ini sangat mudah dilakukan, daun dan batangnya diolah dengan cara merebus kemudian diminum.

Proses pengolahan Tanaman Brotowali (Tinospora Cordifolia) sangat mudah dilakukan. Dalam pengolahan Tanaman Brotowali (Tinospora Cordifolia) harus benar bersih. Tanaman Brotowali (Tinospora Cordifolia) diolah menjadi obat. Dimana daun dan batang di bersihkan dan memasukan air mineral. Kemudian batang Brotowali direbus dan tunggu beberapa menit. Setelah itu air rebusan bisa dikonsumsi secara langsung.

Gula darah adalah gula yang berada didalam darah yang terbentuk dari karbohidrat dalam makanan yang disimpan sebagai glikogen di hati dan otot rangka. Glukosa darah dalam keadaan normal pada pagi hari setelah malam sebelum berpuasa adalah 70-110 mg/dL darah ${ }^{\text {[99-109] }}$. Kadar glukosa darah biasanya kurang dari 120-140 mg/dL pada 2 jam setelah makan atau minum cairan yang mengandung glukosa maupun karbohidrat lainnya.

Untuk mengatasi kenaikan kadar gula dalam darah dapat dilakukan dengan perubahan pola makan yang sehat, dan gunakan obat yang sesuai seperti mengkonsumsi ekstrak daun dan batang brotowali mengelolahnya dengan merebus ${ }^{[110-115]}$. Sehingga lebih mudah dimanfaatkan. Rasa dari ekstrak ini yaitu rasa agak pahit. Air rebusan tersebut dikonsumsi sekali sehari selama seminggu.

2. Uji coba

Dari penelitian yang dilakukan diperoleh data:

Grafik 1. Hubungan Jumlah Konsumsi Ekstrak Terhadap Kadar Gula Darah 


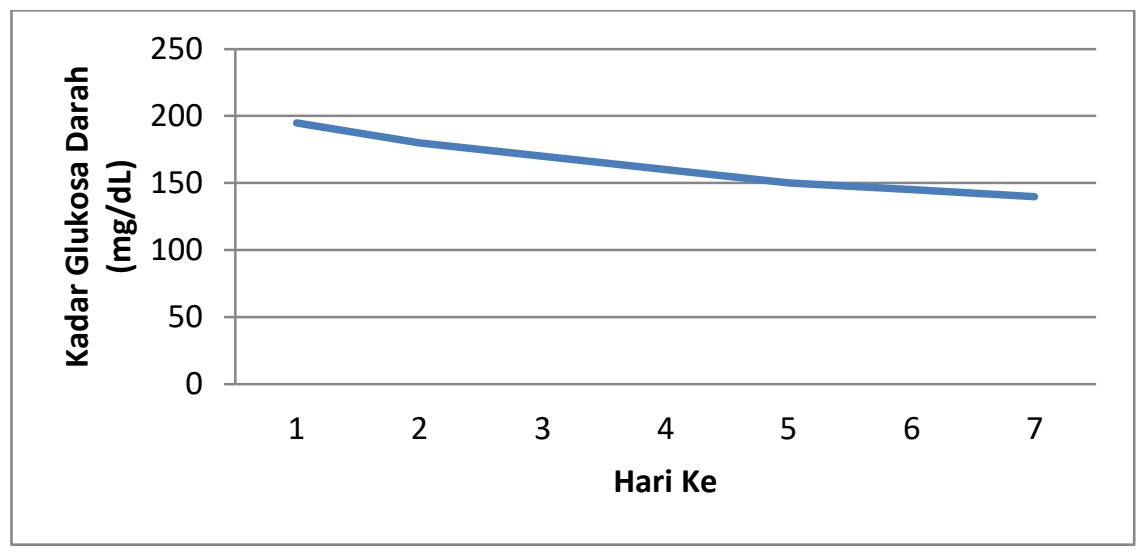

Dengan mengkonsumsi ekstrak batang brotowali 1 gelas dalam sehari maka akan menurunkan kadar gula darah. Setelah konsumsi hari kedua maka kadar gula darah menurun sebesar $15 \mathrm{mg} / \mathrm{dL}$. Pada konsumsi hari terakhir kadar trombosit gula darah menurun menjadi $140 \mathrm{mg} / \mathrm{dL}$ dari 195 $\mathrm{mg} / \mathrm{dL}$.

3. Interaksi

Dari data yang diperoleh terjadi penurunan kadar gula darah selama tujuh hari konsumsi ekstrak batang Brotowali ${ }^{[116-125]}$. Hal tersebut dapat terjadi karena dalam daun dan batang brotowali mengandung flavonoid, alkaloid, saponin dan tannin. Brotowali mengandung zat pahit tinokriposid, damar lunak, pati, glikosida, pikroretosid, harsa, kolumbin, kaokulin atau pikrotoksin, dan beberapa alkaloid seperti aporfin, beberin, dan palmatin ${ }^{[126-135]}$. Senyawa yang paling penting yang terdapat pada batang brotowali diduga merupakan senyawa tinokrisposid yang memiliki aktivitas sebagai antimalaria, anti inflamasi, dan antidiabetes. Brotowali sendiri dapat merangsang produksi insulin dari sel beta di pangkreas. Brotowali juga dapat meningkatkan penyerapan glukosa oleh otot. Sehingga dapat membantu menurunkan atau mengobati diabetes ${ }^{[136-145]}$.

Brotowali mengandung banyak senyawa kimia yang berkhasiat untuk menyembuhkan berbagai macam penyakit. Kandungan senyawa kimia berkhasiat sebagai obat tersebut terdapat diseluruh bagian tanamannya mulai dari akar, batang sampai daun. Akar brotowali mengandung senyawa antimikroba berberin dan kolumbin ${ }^{[145-150]}$. Komponen utama yang telah diidentifikasi aktif adalah terpenoid. Senyawa terpenoid yang berperan menurunkan serum gula darah pada diabetes adalah borapentol B. Adapun mekanisme pengobatan oral untuk penderita DM yaitu dengan cara penghambatan kerja enzim alfa glukosidase yang berperan dalam konversi karbohidrat menjadi glukosa. Dengan dihambatnya kerja enzim alfa glucosidase menyebabkan kadar glukosa dalam darah dapat dikembalikan dalam batas normal.

Disini dapat diketahui peran tanaman Brotowali sebagai suatu katalis yang berasal dari bahan alam. Hal tersebut dapat diamati dengan adanya proses katalitik dari tanaman Brotowali yang dapat berpengaruh proses 
menurunkan kadar gula dalam darah. Proses tersebut dapat berlangsung karena adanya reaksi antara senyawa yang terkandung didalam tanaman brotowali dengan kadar gula dalam darah itu tersebut.

\section{Kesimpulan}

1. Ekstrak batang brotowali dapat dibuat dari 2 batang Brotowali ukuran $20 \mathrm{~cm}$ dengan 2 gelas air mineral yang menghasilkan satu gelas ekstrak batang brotowali.

2. Ekstrak batang brotowali dapat menurunkan kadar gula darah dalam tubuh setelah pemakaian selama satu minggu atau tujuh hari.

3. Ekstrak pada batang dapat menurunkan kadar gula. Dimana bahan tersebut mengandung flavonoid, tannin, alkaloid, dan saponin.

\section{REFERENSI}

[1] Hidayani, T. (2018) "GRAFTING POLIPROPILENA DENGAN MALEAT ANHIDRIDA SEBAGAI PENGIKAT SILANG DENGAN INISIATOR BENZOIL PEROKSIDA", EKSAKTA: Berkala Ilmiah Bidang MIPA, 19(1), pp. 56-62. doi: 10.24036/eksakta/vol19-iss 1/127.

[2] Ruswandi, R. (2018) "Determination of Fructose Content resulted by Inulin Hydrolysis with DNS as Oxidizer", EKSAKTA: Berkala Ilmiah Bidang MIPA, 19(1), pp. 14-23. doi: 10.24036/eksakta/vol19iss $1 / 102$.

[3] Masykur, Fathurrahman ( Fakultas Geografi UGM ), Sudrajat, Sudrajat ( Fakultas Geografi UGM ).2013. ANALISIS POTENSI EMISI KARBON PADA AKTIVITAS PRODUKSI TANAMAN PADI (Kasus Desa Hargomulyo, Kecamatan Gedhangsari, Gunungkidul). Jurnal Bumi Indonesia. Volume 2, NO 3

[4] Tasim, Lina, Santoso, I R. S., Rombang, W A. R.2013. Analisis Pemahaman Konsep Reaksi Kimia Melalui Pendekatan Pembelajaran Langsung Pada Siswa SMP Negeri 13 Tidore Kepulauan. JSME MIPA UNIMA. Vol 1, No 3

[5] Zainul, R., Effendi, J., \& M. (2018, December 10). Phototransformation of Linear Alkylbenzene Sulphonate (LAS) Surfactant Using $\mathrm{ZnO}-\mathrm{CuO}$ Composite Photocatalyst. https://doi.org/10.31227/osf.io/fec28

[6] Ahmad, Ahyar. 2012. Teknik Immunoassay Dalam Analisis Keamanan Pangan Dasar-Dasar Reaksi Kimia Dan Penerapannya. Marina Chimica Acta. Vol 6, no 1

[7] Kurnia, Arif, Awaluddin, Amir, Saputra, Edy.2014. PENGARUH KONSENTRASI REAKTAN TERHADAP KONVERSI LIMBAH PELEPAH SAWIT MENJADI ASAM LEVULINAT DENGAN METODE HIDROLISIS MENGGUNAKAN KATALIS ASAM 
SULFAT.Jurnal Online Mahasiswa (JOM) Bidang Matematika dan Ilmu Pengetahuan Alam. Vol 1, No 2

[8] R, Yolanda., Yelmida, Yelmida, Zahrina, Zahrina.2014. Sintesis Zeolit 4a Dari Fly Ash Sawit Dengan Variasi Perbandingan Volume Reaktan Dan Kecepatan Pengadukan. Jurnal Online Mahasiswa (JOM) Bidang Teknik dan Sains. Vol 1, No 2

[9] Zuhrina Masyithah, Eric Wirtanto, Michael Lim, ( Universitas Sumatera Utara ).2012. KAJIAN KEMURNIAN DAN PENGARUH NISBAH PEREAKSI, pH AWAL REAKSI DAN SUHU REAKSI TERHADAP NILAI CMC \& HLB NATRIUM LIGNOSULFONAT.Jurnal Teknik Kimia USU.Vol 1, No 1

[10] Gunawan, I W. G.2009. STUDI PERBANDINGAN HASIL SINTESIS METIL-N(2,3-XILIL)ANTRANILAT DENGAN PEREAKSI DIAZOMETANA DAN BF3-METANOL. Journal of Chemistry.Vol. 3, No. 1

[11] Sari, A. (2017) "POTENSI ANTIOKSIDAN ALAMI PADA EKSTRAK DAUN JAMBLANG (Syzigium cumini (L.) Skeels)", EKSAKTA: Berkala Ilmiah Bidang MIPA, 18(02), pp. 107-112. doi: 10.24036/eksakta/vol18-iss02/61

[12] Yanuar, F., Tillah, M. and Devianto, D. (2018) "Modeling of Human Development Index Using Ridge Regression Method", EKSAKTA: Berkala Ilmiah Bidang MIPA, 19(2), pp. 1-11. doi: 10.24036/eksakta/vol19-iss2/134

[13] Ahmad, Ahyar.2012. TEKNIK IMMUNOASSAY DALAM ANALISIS KEAMANAN PANGAN Dasar-Dasar Reaksi Kimia dan Penerapannya. MARINA CHIMICA ACTA.Vol 6, No 1

[14] Suyitno ( Jurusan Teknik Mesin Fakultas Teknik, UNS, Surakarta ).2009. Perumusan Laju Reaksi dan Sifat-Sifat Pirolisis Lambat Sekam Padi Menggunakan Metode Analisis Termogravimetri. Jurnal Teknik Mesin. Vol 11, No 1

[15] Sudiana, I Nyoman, Zamrun Firihu, Muhammad.2015. PERCEPATAN REAKSI KIMIA DENGAN PEMANASAN MIKROWAVE. Jurnal Aplikasi Fisika. Vol 11, No 2

[16] Sanjaya, H. (2017) "DEGRADASI METHYLENE BLUE MENGGUNAKAN KATALIS ZnO-PEG DENGAN METODE FOTOSONOLISIS", EKSAKTA: Berkala Ilmiah Bidang MIPA, 18(02), pp. 21-29. doi: 10.24036/eksakta/vol18-iss02/45.

[17] Zainul, R., Alif, A., Aziz, H., Arief, S., \& Darajat, S. (2015). Modifikasi dan Karakteristik IV Sel Fotovoltaik $\mathrm{Cu} 2 \mathrm{o} / \mathrm{Cu}-\mathrm{Gel}$ Na2so4 Melalui Iluminasi Lampu Neon. Eksakta, 2, 50

[18] Mukaromah, Ana Hidayah.2005. EFEKTIVITAS FOTODEGRADASI P-KLOROFENOL DENGAN KATALIS TIO2. JURNAL LITBANG. Vol 2, No 2 
[19] M., Sanjaya, H., \& Zainul, R. (2018, August 11). Characterization of napa soil and adsorption of $\mathrm{Pb}$ (II) from aqueous solutions using on column method. https://doi.org/10.31227/osf.io/t8fh9

[20] Zainul, R., \& Dewata, I. (2015). Determination of pH-BOD-COD and degradation in batang arau watersheds at Padang city

[21] Sanjaya, H. (2018) "DEGRADASI METIL VIOLET MENGGUNAKAN KATALIS ZnO-TiO2 SECARA FOTOSONOLISIS", EKSAKTA: Berkala Ilmiah Bidang MIPA, 19(1), pp. 91-99. doi: 10.24036/eksakta/vol19-iss1/131.

[22] Agus Wibowo, Agus Wibowo ( Jurusan Teknik Mesin Fakultas Teknik Universitas Pancasakti Tegal Jl. Halmahera KM I Tegal, Jawa Tengah ).2010. LAJU REAKSI PENCAMPURAN MINYAK JARAK DAN AIR PADA HYDROGEN REFORMER MENGGUNAKAN PEMANAS DAN KATALIS. Prosiding Seminar Nasional Sains Dan Teknologi Fakultas Teknik. Vol 1, No 1

[23] Octarina, Yusrika, Prasetiyono, Eva, Febrianti, Dwi, Robin, Robin.2018. EFEKTIVITAS EKSTRAK DAUN CIPLUKAN (Physalis angulata L.) TERHADAP SISTEM KEKEBALAN TUBUH IKAN NILA (Oreochromis niloticus). Jurnal Riset Akuakultur. Vol 13, No 3

[24] Sari, A. (2017) "POTENSI ANTIOKSIDAN ALAMI PADA EKSTRAK DAUN JAMBLANG (Syzigium cumini (L.) Skeels)", EKSAKTA: Berkala Ilmiah Bidang MIPA, 18(02), pp. 107112. doi: 10.24036/eksakta/vol18-iss02/61.

[25] Sukadana, I M., Susanah Rita, Wiwik, R. Koreh, Frida.2007. ISOLASI DAN IDENTIFIKASI SENYAWA ANTIMAKAN DARI BATANG TUMBUHAN BROTOWALI (Tinospora tuberculata BEUMEE.). Journal of Chemistry. Vol. 1, No. 2

[26] Kardinan, Agus ( Balittro, Bogor ) , Iskandar, Momo ( Balittro, Bogor ) , Hernani, Hernani ( Balittro, Bogor ).1998. PENGARUH EKSTRAK BATANG BROTOWALI TERHADAP AKTIVITAS BIOLOGI SERANGGA TRIBOLIUM CASTANEUM Hbst. Warta Tumbuhan Obat Indonesia. Vol 4, No 2

[27] Sudardi, Bani.2002. Konsep Pengobatan Tradisional Menurut Primbon Jawa. Jurnal Humaniora. Vol 14, No 1

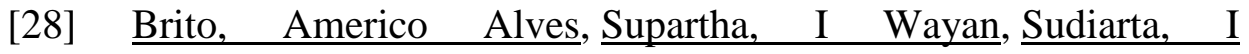
Putu.2016.KERAGAMAN $\quad$ Liriomyza spp. (DIPTERA;AGROMYZIDAE) YANG BERASOSIASI DENGAN BERBAGAI JENIS TANAMAN SAYURAN DAN TUMBUHAN LIAR DI TIMOR LESTE. Journal of Agricultural Science and Biotechnology. Vol 5 No 1

[29] Wahyuno, Dono ( Balittro, Bogor ), Manohara, Dyah ( Balittro, Bogor ).1998. TINJAUAN PENYAKIT BERCAK BERTEPUNG PADA DAUN BROTOWALI. Warta Tumbuhan Obat Indonesia. Vol 4 , No 2 
[30] Soemiati, Atiek ( Jurusan F.armasi FMIPA UI ), Katrin, Katrin ( Jurusan Farmasi FMIPA UI ), Rahamah, Ema ( Jurusan Farmasi FMIPA UI ).1998. UJI DAYA ANTIBAKTERIA INFUS BATANG BROTOWALI TERHADAP BEBERAPA KUMAN STANDAR. Warta Tumbuhan Obat Indonesia. Vol 4, No 2

[31] Parbuntari, H., Prestica, Y., Gunawan, R., Nurman, M. and Adella, F. (2018) "Preliminary Phytochemical Screening (Qualitative Analysis) of Cacao Leaves (Theobroma cacao L.)", EKSAKTA: Berkala Ilmiah Bidang MIPA, 19(2), pp. 40-45. doi: 10.24036/eksakta/vol19-iss2/142.

[32] Iskandar, I., Horiza, H. and Fauzi, N. (2017) "EFEKTIVITAS BUBUK BIJI PEPAYA (Carica Papaya Linnaeaus) SEBAGAI LARVASIDA ALAMI TERHADAP KEMATIAN LARVA AEDES AEGYPTY TAHUN 2015", EKSAKTA: Berkala Ilmiah Bidang MIPA, 18(01), pp. 12-18. doi: 10.24036/eksakta/vol18-iss01/12.

[33] S., Susiana Prasetyo ( Jurusan Teknik Kimia, Fakultas Teknologi Industri Universitas Katolik Parahyangan, Bandung ), K., A. Prima ( Jurusan Teknik Kimia, Fakultas Teknologi Industri Universitas Katolik Parahyangan, Bandung ) , Yosephine, Felicia ( Jurusan Teknik Kimia, Fakultas Teknologi Industri Universitas Katolik Parahyangan, Bandung ).2011. PENGARUH RASIO BIJI TEH / PELARUT AIR DAN TEMPERATUR PADA EKSTRAKSI SAPONIN BIJI TEH SECARA BATCH. Research Report Engineering Science. Vol 2

[34] SANI ANWAR, YUNITA ARIAN, ARTIKA, I MADE, DANURI, HASIM.2009. Fractionation and Characterization of Tannin Acyl Hydrolase from Aspergillus niger. HAYATI Journal of Biosciences. Vol 16, No 3

[35] NK, Rahmawaty, Iskandar, Burhanuddin, Albar, Husain, Daud, Dasril.2012. Faktor Risiko Serangan Berulang Demam Rematik/Penyakit Jantung Rematik. Sari Pediatri. Vol 14, No 3

[36] Rohmani, Afiana, Anggraini, Merry Tiyas.2012. PEMAKAIAN ANTIBIOTIK PADA KASUS DEMAM BERDARAH DENGUE ANAK DI RUMAH SAKIT ROEMANI SEMARANG TAHUN 2010. PROSIDING SEMINAR NASIONAL

[37] Suwandi, Suwandi, Mazid, Abdul, Surahman, Surahman.2001. Populasi Bakteri Antagonistik terhadap Fusarium sp. dari Rizosfer Lada Sehat dan Sakit Kuning. Jurnal Perlindungan Tanaman Indonesia. Vol 7, No 1

[38] Kristanti, Erva Elli ( STIKES RS. Baptis Kediri ), Nugroho, Yosef Agung ( STIKES RS. Baptis Kediri ).2011. BATUK EFEKTIF DALAM PENGELUARAN DAHAK PADA PASIEN DENGAN KETIDAKEFEKTIFAN BERSIHAN JALAN NAFAS DI INSTALASI REHABILITASI MEDIK RUMAH SAKIT BAPTIS KEDIRI.Jurnal Penelitian STIKES Kediri.Vol 4, No 2 
[39] Sumanto, Didik, Al Hamidy, Fuad.2004. STUDI EFISIENSI BAHAN UNTUK PEMERIKSAAN INFEKSI KECACINGAN METODE FLOTASI NaCI JENUH MENGGUNAKAN NaCI MURNI DAN GARAM DAPUR. PROSIDING SEMINAR NASIONAL

[40]vMakalalag, Indri Wirasuasty, Wullur, Adeanne, wiyono, Weny. 2013. Uji Ekstrak Daun Binahong ( Anredera cordifolia Steen.) Terhadap kadar Gula Darah Pada Tikus Putih Jantan Galur Wistar ( Rattus norvegicus) yang Diinduksi Sukrosa. Pharmacon. Vol 2, No 1

[41] Rizki Saputra, M. and Sumarmin, R. (2018) "PENGARUH EKSTRAK DAUN SIRIH MERAH (Piper crocatum Ruiz \& Pav.) TERHADAP GLUKOSA DARAH MENCIT (Mus musculus L.) JANTAN YANG DIINDUKSI SUKROSA", EKSAKTA: Berkala Ilmiah Bidang MIPA, 19(1), pp. 43-55. doi: 10.24036/eksakta/vol19iss $1 / 124$.

[42] Kustarini, Indranilla, Dewi, Sri Sinto, M, Ika Pawitra. 2012. Efek Ekstrak Etanol Morinda Citrifolia L (Mengkudu) Terhadap Kadar Gula Darah, Jumlah Neutrofil, dan Fibronektin Glomerulus Tikus Diabetes Mellitus.

[43] Kaempe, Hindang S., Suryanto, Edi, Kawengian, Shirley E. S. 2013. POTENSI EKSTRAK FENOLIK BUAH PISANG GOROHO (Musa spp.) TERHADAP GULA DARAH TIKUS PUTIH (Rattus norvegicus). MEDIA MEDIKA INDONESIANA. Vol 46, No 3.

[44] chaidir, z., Zainul, R., Nurakhbari, D., \& Salim, M. (2018, July 29).Optimization of Spirulina Platensis Culture for Antioxidant Production. https://doi.org/10.17605/OSF.IO/FD6E4

[41] Anhar, A., Sumarmin, R., \& Zainul, R. (2016). Measurement of Glycemic Index of West Sumatera Local Rice Genotypes for Healthy Food Selection. Journal of Chemical and Pharmaceutical Research, $8(8), 1035-1040$

[45] Utami, Rahayu, Fernando, Armon, Sari, Indah Puspita, Furi, Mustika.2017. Penetapan Kadar Berberin dari Ekstrak Etanol Akar dan Batang Sekunyit (Fibraurea Tinctoria Lour) dengan Metode KCKT. Jurnal Sains Farmasi \& Klinis. Vol 3, No 2

[46] WINARSI, HERY ( Jenderal Soedirman University ) , PURWANTO, AGUS ( Margono Soekarjo General Hospital Purwokerto ).2010. Soy Germed Protein Plus $\mathrm{Zn}$ as an Inducer Insulin Secretion on Type-2 Diabetes Mellitus. HAYATI Journal of Biosciences. Vol 17, No 3

[47] Mukaromah, Ummu, Susetyorini, Sri Hetty, Aminah, Siti.2010. KADAR VITAMIN C, MUTU FISIK, pH DAN MUTU ORGANOLEPTIK SIRUP ROSELLA (Hibiscus Sabdariffa, L) BERDASARKAN CARA EKSTRAKSI. JURNAL PANGAN DAN GIZI. Vol 1, No 1 
[48] Momuat, Lidya I, Sangi, Meiske S, Purwati, Ni Putu.2012. PENGARUH VCO MENGANDUNG EKSTRAK WORTEL TERHADAP PEROKSIDASI LIPID PLASMA. JURNAL ILMIAH SAINS. Vol 11, No 2

[49] Sumarmin, R. (2018) "Pengaruh Ekstrak Kulit Buah Manggis (Garcinia mangostana L.) terhadap Histologis Pankreas Mencit (Mus musculus L. Swiss Webster) yang Diinduksi Sukrosa", EKSAKTA: Berkala Ilmiah Bidang MIPA, 19(1), pp. 100-112. doi: 10.24036/eksakta/vol19-iss1/123.

[50] Samah, S. (2017) "KARAKTERISASI PLASTIK BIODEGRADABEL DARI LDPE-g-MA DAN PATI TANDAN KOSONG SAWIT", EKSAKTA: Berkala Ilmiah Bidang MIPA, 18(02), pp. 30-38. doi: 10.24036/eksakta/vol18-iss02/48.

[51] Lubis, A. P., \& Zainul, R. (2018, November 5). Interaksi Molekuler Amonium Hidroksida. https://doi.org/10.31227/osf.io/jht3b

[52] Zainul, R. (2018, August 16). Design and Modification of Copper Oxide Electrodes for Improving Conversion Coefficient Indoors Lights (PV-Cell) Photocells. https://doi.org/10.31227/osf.io/pgn84

[53] Nurfadilah, K. K., \& Zainul, R. (2019, February 3). Kalium Nitrat (KNO3): Karakteristik Senyawa dan Transpor Ion. https://doi.org/10.31227/osf.io/dr8ef

[54] Shafitri, M., \& Zainul, R. (2019, February 3). Vanadium Pentaoksida (V2O5) : Termodinamika Molecular dan Interaksi Ion dalam Larutan. https://doi.org/10.31227/osf.io/jgmvd

[55] Zainul, R., Effendi, J., \& M. (2018, December 10). Phototransformation of Linear Alkylbenzene Sulphonate (LAS) Surfactant Using $\mathrm{ZnO}-\mathrm{CuO}$ Composite Photocatalyst. https://doi.org/10.31227/osf.io/fec28

[56] Warlinda, Y. A., \& Zainul, R. (2019, January 29). Asam Posfat (H3PO4): Ionic Transformation of Phosphoric Acid in Aqueous Solution. https://doi.org/10.31227/osf.io/s3y8v

[57] Zainul, R. (2018, August 16). Determination of the half-life and the quantum yield of $\mathrm{ZnO}$ semiconductor photocatalyst in humic acid. https://doi.org/10.31227/osf.io/e8a9x

[58] Dwynda, I., \& Zainul, R. (2018, November 19). Boric Acid (H3 (BO3): Recognize The Molecular Interactions in Solutions. https://doi.org/10.31227/osf.io/6wead

[59] Y., \& Zainul, R. (2018, November 18). SILVER SULFATE (Ag2SO4): MOLECULAR ANALYSIS AND ION TRANSPORT. https://doi.org/10.31227/osf.io/n8g9k

[60] Yulis, R., Zainul, R., \& M. (2018, December 10). DESAIN DAN KARAKTERISASI SEL SURYA SISTEM ELEKTRODA TEMBAGA (I) OKSIDA (CU2O/AI) MODEL PIPA PADA LARUTAN NATRIUM SULFAT (Na2SO4). https://doi.org/10.31227/osf.io/m43js 
[61] Yanti, C. F., \& Zainul, R. (2018, December 2). A Review Ba (OH)2 : Transpor Ionik pada Barium Hidroksida di dalam Air dengan Konsep Termodinamika. https://doi.org/10.31227/osf.io/fsbq3

[62] Dinata, A. A., Rosyadi, A. M., Hamid, S., \& Zainul, R. (2018, October 15). A Review CHEMICAL VAPOR DEPOSITION : PROCESS AND APPLICATION. https://doi.org/10.31227/osf.io/yfeau

[63] P, O. M., A, L. G., S, A. Y. M., \& Zainul, R. (2018, October 12). A Review Grinding : Teknik dan Prinsip Dasar pada Pengolahan Material.

https://doi.org/10.31227/osf.io/trv4q P, O. M., A, L. G., S, A. Y. M., \& Zainul, R. (2018, October 12). A Review Grinding : Teknik dan Prinsip Dasar pada Pengolahan Material. https://doi.org/10.31227/osf.io/trv4q

[64] Febriani, S. S., Yolanda, T., Arianti, V. A., \& Zainul, R. (2018, October 12). A Review Solid Stated : Principles and Methode. https://doi.org/10.31227/osf.io/7us4x

[65] Putri, D. F., Ritonga, H. M., Murdiati, V., \& Zainul, R. (2018, October 15). A REVIEW WHAT IS HYDROTHERMAL ?. https://doi.org/10.31227/osf.io/dm56c

[66] Husna, H., \& Zainul, R. (2019, February 3). A Review : Aspek Termodinamika LiNO3 dalam Larutannya. https://doi.org/10.31227/osf.io/45mbd

[67] Husna, A. D., \& Zainul, R. (2019, February 4). Analisis Molekular dan Karakteristik Hidrogen Sianida (HCN). https://doi.org/10.31227/osf.io/7xej9

[68] Kristy, D. P., \& Zainul, R. (2019, February 3). Analisis Molekular dan Transpor Ion Natrium Silikat. https://doi.org/10.31227/osf.io/8ac4m

[69] Yuliani, F., \& Zainul, R. (2018, November 13). Analisis Termodinamika Molekul Magnesium Sulphate (MgSO4). https://doi.org/10.31227/osf.io/uxz4y

[70] Hakimi, A., \& Zainul, R. (2019, January 31). Asam Arsenat (H3AsO4) : Analisis Molekular dan Karakteristik Senyawa. https://doi.org/10.31227/osf.io/e486z

[71] Alfionita, T., \& Zainul, R. (2019, January 29). Calcium Chloride $(\mathrm{CaCl} 2)$ : Characteristics and Molecular Interaction in Solution. https://doi.org/10.31227/osf.io/m37xj

[72] M., Sanjaya, H., \& Zainul, R. (2018, August 11). Characterization of napa soil and adsorption of $\mathrm{Pb}$ (II) from aqueous solutions using on column method. https://doi.org/10.31227/osf.io/t8fh9

[73] Rahmadhanty, S., \& Zainul, R. (2018, December 24). DESIGN OF HUMAT ACID SOLID SOLUTION REACTOR THROUGH PHOTOTRANSFORMATION OF COPPER OXIDE (CuO) SEMICONDUCTOR PLATE. https://doi.org/10.31227/osf.io/yhd9x 
[74] Desideria, S., Dj, L., \& Zainul, R. (2018, November 6). Deskripsi Keterampilan Proses Sains Peserta Didik Kelas XI IPA pada Materi Larutan Penyangga di SMAN 15 Padang. https://doi.org/10.31227/osf.io/t5q89

[75] Rahmadhanty, S., \& Zainul, R. (2018, December 24). DESIGN OF HUMAT ACID SOLID SOLUTION REACTOR THROUGH PHOTOTRANSFORMATION OF COPPER OXIDE (CuO) SEMICONDUCTOR PLATE. https://doi.org/10.31227/osf.io/yhd9x

[76] Zainul, R. (2018, August 16). Determination of the half-life and the quantum yield of $\mathrm{ZnO}$ semiconductor photocatalyst in humic acid. https://doi.org/10.31227/osf.io/e8a9x

[77] Putri, G. A., H., \& Zainul, R. (2018, September 25). DEVELOPMENT OF PERIODIC TABLE INTERACTIVE INSTRUCTIONAL MULTIMEDIA IN CHEMISTRY LESSON FOR Xth GRADE SMA / MA. https://doi.org/10.31227/osf.io/2hsme

[78] Zainul, R. (2018, August 16). DISAIN, METODE DAN PENGGUNAAN SOFTWARE PEMBELAJARAN KIMIA BERBASIS IT UNTUK AKTIVITAS KELAS DAN LABORATORIUM BERBASIS INKUIRI TERBIMBING. https://doi.org/10.31227/osf.io/psf5t

[79] Zainul, R. (2018, August 16). Effect of Temperature and Particle Motion against the ability of $\mathrm{ZnO}$ Semiconductor Photocatalyst in Humic Acid. https://doi.org/10.31227/osf.io/wnygb

[80] Zainul, R. (2018, August 16). Effect of Temperature and Particle Motion against the ability of $\mathrm{ZnO}$ Semiconductor Photocatalyst in Humic Acid. https://doi.org/10.31227/osf.io/wnygb

[81] Lubis, A. P., \& Zainul, R. (2018, November 5). Interaksi Molekuler Amonium Hidroksida. https://doi.org/10.31227/osf.io/jht3b

[82] chaidir, z., Fadjria, N., A., \& Zainul, R. (2018, August 11). ISOLATION AND MOLECULAR IDENTIFICATION OF FRESHWATER MICROALGAE IN MANINJAU LAKE WEST SUMATERA. https://doi.org/10.31227/osf.io/nbcuf

[83] Sari, M., \& Zainul, R. (2018, November 19). Kalium Dikromat (K2Cr2O7) Spektroskopi dan Transpor K2Cr2O7. https://doi.org/10.31227/osf.io/w92je

[84] Feronika, N. I., \& Zainul, R. (2018, November 19). Kalium Permanganat: Termodinamika Mengenai Transport Ionik dalam Air. https://doi.org/10.31227/osf.io/g6eyk

[85] Delvi, I. P., \& Zainul, R. (2019, February 3). Mercury (II) Nitrate (Hg (NO3)2): Interaksi Molekul dan Adsorpsi Hg dengan Karbon Aktif. https://doi.org/10.31227/osf.io/eqyax

[86] Putri, G. E., Arief, S., Jamarun, N., Gusti, F. R., \& Zainul, R. (2018, December 10). Microstuctural Analysis and Optical Properties of Nanocrystalline Cerium Oxides Synthesized by Precipitation Method. https://doi.org/10.31227/osf.io/qcz4y 
[87] Jumalia, R., \& Zainul, R. (2019, February 3). Natrium Karbonat : Termodinamika dan Transport Ion. https://doi.org/10.31227/osf.io/y2vq9

[88] Sari, E. S. J., \& Zainul, R. (2019, January 31). Nitrogen Triflorida (NF3) : Termodinamika dan Transpor Elektron NF3. https://doi.org/10.31227/osf.io/3nzrh

[89] chaidir, z., Zainul, R., Nurakhbari, D., \& Salim, M. (2018, July 29). Optimization of Spirulina Platensis Culture for Antioxidant Production. https://doi.org/10.17605/OSF.IO/FD6E4

[90] Artika, P. I., \& Zainul, R. (2018, November 19). Potassium Bromide $(\mathrm{KBr})$ : Transformasi ionik dan sifat temodinamika dalam Larutan. https://doi.org/10.31227/osf.io/a5hyz

[91] Liza, Y. M., Yasin, R. C., Maidani, S. S., \& Zainul, R. (2018, October 9). SOL GEL : PRINCIPLE AND TECHNIQUE (A REVIEW). https://doi.org/10.31227/osf.io/2cuh8

[92] Harlis, Wa Ode, Septiana, Andi. 2017. GAMBARAN HISTOLOGI TESTIS MENCIT (MUS MUSCULUS, L.) SETELAH PEMBERIAN EKSTRAK TUMBUHAN BROTOWALI (TINOSPORA CRISPA, L). Jurnal BioWallacea. Vol 4, No 1.

[93] Rosidah, Idah ( Pusat Teknologi Farmasi dan Medika- Badan Pengkajian dan Penerapan Teknologi ), Bahua, Humiaty, Mufidah, Rima, Pongtuluran, Olivia Bunga. 2015. Pengaruh Kondisi Proses Ekstraksi Batang Brotowali (Tinospora crispa (L) Hook.f \& Thomson) Terhadap Aktivitas Hambatan Enzim Alfa Glukosidase. Media Penelitian dan Pengembangan Kesehatan. Vol 25, No 4 Des.

[94] Harwoko, Harwoko, Choironi, Nur Amalia. 2016. STANDARDISASI KUALITAS EKSTRAK BATANG BROTOWALI (Tinospora crispa). Traditional Medicine Journal. Vol 21, No 1.

[95] Nuryanti, Nuryanti ( Jurusan Farmasi Fakultas Ilmu-Ilmu Kesehatan Universitas Jenderal Soedirman ), Warsinah, Warsinah ( Jurusan Farmasi Fakultas Ilmu-Ilmu Kesehatan Universitas Jenderal Soedirman ), Rohman, Gitanti ( Jurusan Farmasi Fakultas Ilmu-Ilmu Kesehatan Universitas Jenderal Soedirman ), Argi, Windhiana Sapti ( Jurusan Farmasi Fakultas Ilmu-Ilmu Kesehatan Universitas Jenderal Soedirman ). 2015. AKTIVITAS ANTIFUNGI SHAMPO DAN KRIM EKSTRAK ETANOLIK BATANG BROTOWALI TERHADAP Pityrosporum ovale DAN Trichophyton mentagrohytes. Kartika Jurnal Ilmiah Farmasi. Vol 3, No 2.

[96] Dumeva, Agustiani, Syarifah, Syarifah, Fitriah, Syahidah. 2016. PENGARUH EKSTRAK BATANG BROTOWALI (Tinospora crispa) TERHADAP KEMATIAN LARVA NYAMUK Aedes aegypti. Biota. Vol 2 No 2.

[97] Marlina, Marlina ( Universitas Negeri Makassar ) , Sudding, Sudding ( Universitas Negeri Makassar ) , Salempa, Pince ( 
Universitas Negeri Makassar ). 2015. Isolasi Dan Identifikasi

Senyawa Metabolit Sekunder Ekstrak n-Heksan Batang Brotowali (Tinospora crispa Linn). C H E M I C A. Vol 16, No 2

[98] Triyono, Agus ( Balai Besar Penelitian dan Pengembangan Tanaman

Obat dan Obat Tradisional Badan Litbang Kesehatan, Kementerian

Kesehatan RI Jl. Raya Lawu, Tawangmangu, Karanganyar, Jawa

Tengah ), ., Saryanto ( Balai Besar Penelitian dan Pengembangan

Tanaman Obat dan Obat Tradisional Badan Litbang Kesehatan,

Kementerian Kesehatan RI Jl. Raya Lawu, Tawangmangu, Karanganyar, Jawa Tengah ). 2012. UJI TOKSISITAS AKUT DAN SUBKRONIK EKSTRAK BROTOWALI (Tinospora crispa (L) Miers). Jurnal Tumbuhan Obat Indonesia. Vol 5, No 2.

[99] Amma, Nur Rahmi. 2011. EFEK HIPOGLIKEMIK EKSTRAK DAUN MURBEI (MORUS MULTICAULIS) TERHADAP KADAR GLUKOSA DARAH TIKUS DIABETES MELITUS. Sainstek. Vol 6, No 1

[100] Hartoyo, Arif, ., Sukarno, Rohmawati, Erma. 2010. PENGARUH

FRAKSI NONPROTEIN KACANG KOMAK (Lablab purpureus (L.) Sweet) TERHADAP KADAR GLUKOSA DARAH DAN MALONALDEHIDA TIKUS DIABETES. Jurnal Teknologi Dan Industri Pangan. Vol 21, No 1

[101] Pasaribu, Fidayani ( Fakultas Farmasi Universitas Sumatera Utara ) , Sitorus*, Panal ( Fakultas Farmasi Universitas Sumatera Utara ) , Bahri, Saiful ( Fakultas Farmasi Universitas Sumatera Utara ). 2012. Uji Ekstrak Etanol Kulit Buah Manggis (Garcinia mangostana L.) Terhadap Penurunan Kadar Glukosa Darah. Journal of Pharmaceutics and Pharmacology. $\quad$ Vol $1, \quad$ No 1. [102] Inawati, Syamsudin Syamsudin, Hendiq Winarno.2006. Pengaruh Ekstrak Daun Inai (Lawsonia inermis Linn.) Terhadap Penurunan Kadar Glukosa, Kolesterol Total dan Trigliserida Darah Mencit yang Diinduksi Aloksan. Jurnal Kimia Indonesia. Vol 1, No 2 [103] LUKITAWATI, WINDY ( Prodi Kimia, Jurusan Kimia, Universitas Negeri Surabaya ). 2013. PENGARUH TEH KOMBUCHA TERHADAP KADAR GLUKOSA DARAH Rattus norvegicus (THE EFFECT OF KOMBUCHA TEA ON BLOOD GLUCOSE LEVELSOF Rattus novergicus). UNESA Journal of Chemistry Volume 2, Number 1

[104] Yuda, I Ketut Angga, Anthara, Made Suma, Dharmayudha, Anak Agung Gde Oka. 2013. Identifikasi Golongan Senyawa Kimia Estrak Etanol Buah Pare (Momordica charantia) dan Pengaruhnya Terhadap Penurunan Kadar Glukosa Darah Tikus Putih Jantan (Rattus novergicus) yang Diinduksi Aloksan. Buletin Veteriner Udayana. Vol. 5 No. 2 Agustus 2013

[105] NOOR SOESANTI HANDAJANI (Jurusan Biologi FMIPA Universitas Sebelas Maret (UNS) Surakarta 57126. ) , RUBEN 
DHARMAWAN (Program Studi Biosains, Program Pascasarjana, Universitas Sebelas Maret, Surakarta 57126, Jawa Tengah, Indonesia ). 2009. Pengaruh VCO terhadap hitung jenis leukosit, kadar glukosa dan kreatinin darah Mus musculus Balb/c hiperglikemi dan tersensitisasi ovalbumin. Bioteknologi. Vol. 6, No. 1, 2009

[106] Evacuasiany, Endang ( Universitas Kristen Maranatha ), William G., Hendra ( Universitas Kristen Maranatha ), Santosa, Slamet ( Universitas Kristen Maranatha ). 2004. Pengaruh Biji Jengkol (Pithecellobium jiringa) terhadap Kadar Glukosa Darah Mencit Galur Balb/c. Jurnal Kedokteran Maranatha. Vol 4, No 1 (2004)

[107] Farman S, Farman S ( Mahasiswa Fakultas Kedokteran Universitas Diponegoro Semarang ), Widodo S, Aryoko ( Dosen bagian kimia kedokteran Fakultas Kedokteran Universitas Diponegoro Semarang ). 2012. PENGARUH PEMBERIAN EKSTRAK KACANG MERAH (Vigna Angularis) TERHADAP PENURUNAN KADAR GLUKOSA DARAH TIKUS WISTAR JANTAN YANG DIBERI BEBAN GLUKOSA. Jurnal Kedokteran Diponegoro. Vol 1, No. 1

[108] Cyntia, Victoria ( Mahasiswa Fakultas Kedokteran UNDIP Semarang ), Widodo, Aryoko ( Staf Pengajar Fakultas Kedokteran UNDIP Semarang ). 2012. PENGARUH PEMBERIAN EKSTRAK DAUN KUMIS KUCING (Orthosiphon aristatus) TERHADAP PENURUNAN KADAR GLUKOSA DARAH TIKUS WISTAR YANG DIINDUKSI ALOKSAN. Jurnal Kedokteran Diponegoro. Vol. 1 No 1.

[109] CANDRA, STEFANI ( Mahasiswa Fakultas Kedokteran Universitas Diponegoro Semarang ), DK, Kusmiyati ( Staf Pengajar Fakultas Kedokteran Universitas Diponegoro Semarang ), Widodo, Y. L. Aryoko ( Staf Pengajar Fakultas Kedokteran Universitas Diponegoro Semarang. 2012. PENGARUH PEMBERIAN EKSTRAK BUAH BELIMBING WULUH (Averrhoa blimbi L.) TERHADAP PENURUNAN KADAR GLUKOSA DARAH TIKUS WISTAR YANG DIINDUKSI ALOKSAN. Jurnal Kedokteran Diponegoro. Vol. 1 No 1.

[110] Huda, N. (2017) "PENGARUH EKSTRAK SAMBILOTO (Andrographis paniculata Nees.) TERHADAP SIKLUS ESTRUS MENCIT (Mus musculus L. Swiss Webster)", EKSAKTA: Berkala Ilmiah Bidang MIPA, 18(02), pp. 69-76. doi: 10.24036/eksakta/vol18-iss02/55.

[111] Sumarmin, R. (2018) "Pengaruh Ekstrak Kulit Buah Manggis (Garcinia mangostana L.) terhadap Histologis Pankreas Mencit (Mus musculus L. Swiss Webster) yang Diinduksi Sukrosa", EKSAKTA: Berkala Ilmiah Bidang MIPA, 19(1), pp. 100-112. doi: 10.24036/eksakta/vol19-iss1/123.

[112] Rizki Saputra, M. and Sumarmin, R. (2018) "PENGARUH EKSTRAK DAUN SIRIH MERAH (Piper crocatum Ruiz \& Pav.) 
TERHADAP GLUKOSA DARAH MENCIT (Mus musculus L.) JANTAN YANG DIINDUKSI SUKROSA", EKSAKTA: Berkala Ilmiah Bidang MIPA, 19(1), pp. 43-55. doi: 10.24036/eksakta/vol19iss $1 / 124$.

[113] Sari, A. (2017) "POTENSI ANTIOKSIDAN ALAMI PADA EKSTRAK DAUN JAMBLANG (Syzigium cumini (L.) Skeels)", EKSAKTA: Berkala Ilmiah Bidang MIPA, 18(02), pp. 107112. doi: $10.24036 /$ eksakta/vol18-iss02/61.

[114] Horiza, H., Azhar, M. and Efendi, J. (2017) "EKSTRAKSI DAN KARAKTERISASI INULIN DARI UMBI DAHLIA (Dahlia sp.L) SEGAR DAN DISIMPAN", EKSAKTA: Berkala Ilmiah Bidang MIPA, 18(01), pp. 31-39. doi: 10.24036/eksakta/vol18-iss01/14.

[115] Samah, S. (2017) "KARAKTERISASI PLASTIK BIODEGRADABEL DARI LDPE-g-MA DAN PATI TANDAN KOSONG SAWIT", EKSAKTA: Berkala Ilmiah Bidang MIPA, 18(02), pp. 30-38. doi: 10.24036/eksakta/vol18-iss02/48.

[116] Samah, S. (2017) "KARAKTERISASI PLASTIK BIODEGRADABEL DARI LDPE-g-MA DAN PATI TANDAN KOSONG SAWIT", EKSAKTA: Berkala Ilmiah Bidang MIPA, 18(02), pp. 30-38. doi: 10.24036/eksakta/vol18-iss02/48.

[117] Sumarmin, R. (2018) "Pengaruh Ekstrak Kulit Buah Manggis (Garcinia mangostana L.) terhadap Histologis Pankreas Mencit (Mus musculus L. Swiss Webster) yang Diinduksi Sukrosa", EKSAKTA: Berkala Ilmiah Bidang MIPA, 19(1), pp. 100-112. doi: 10.24036/eksakta/vol19-iss1/123.

[118] Putri, D., Anika, M. and Wahyuni, W. (2019) "Bioinformatics Study Genes Encoding Enzymes Involved in the Biosynthesis of Carotenoids Line Cassava (Manihot esculenta)", EKSAKTA: Berkala Ilmiah Bidang MIPA, 20(1), pp. 10-16. doi: 10.24036/eksakta/vol20iss $1 / 161$.

[119] Parbuntari, H., Prestica, Y., Gunawan, R., Nurman, M. and Adella, F. (2018) "Preliminary Phytochemical Screening (Qualitative Analysis) of Cacao Leaves (Theobroma cacao L.)", EKSAKTA: Berkala Ilmiah Bidang MIPA, 19(2), pp. 40-45. doi: 10.24036/eksakta/vol19-iss2/142.

[120] Parbuntari, H., Prestica, Y., Gunawan, R., Nurman, M. and Adella, F. (2018) "Preliminary Phytochemical Screening (Qualitative Analysis) of Cacao Leaves (Theobroma cacao L.)", EKSAKTA: Berkala Ilmiah Bidang MIPA, 19(2), pp. 40-45. doi: 10.24036/eksakta/vol19-iss2/142.

[121] Iskandar, I., Horiza, H. and Fauzi, N. (2017) "EFEKTIVITAS BUBUK BIJI PEPAYA (Carica Papaya Linnaeaus) SEBAGAI LARVASIDA ALAMI TERHADAP KEMATIAN LARVA AEDES AEGYPTY TAHUN 2015", EKSAKTA: Berkala Ilmiah Bidang MIPA, 18(01), pp. 12-18. doi: 10.24036/eksakta/vol18-iss01/12. 
[122] Amananti, W. (2017) "Analisis Mikrostruktur Lapisan Tipis Tio2:Zno Yang Dideposisikan Diatas Subtrat Kaca Dengan Metode Spray Coating Untuk Degradasi Limbah Zat Warna", EKSAKTA: Berkala Ilmiah Bidang MIPA, 18(02), pp. 210-215. doi: 10.24036/eksakta/vol18-iss02/81.

[123] Horiza, H. (2018) "The influence of the use of activated carbon Fibres of thecane Against the drop in Salinity In the well Dig In RT 003 RW 006Village Cape Town Unggat Tanjungpinang Year 2017”, EKSAKTA: Berkala Ilmiah Bidang MIPA, 19(1), pp. 1-6. doi: 10.24036/eksakta/vol19- iss1/97.

[124] Hidayat, D. (2018) “ANALISIS RESPON PENGONTROL ONOFF PADA KENDALI UMPAN BALIK SISTEM FISIS ELEKTRONIK", EKSAKTA: Berkala Ilmiah Bidang MIPA, 19(1), pp. 118-124. doi: 10.24036/eksakta/vol19-iss1/119.

[125] Samah, S. (2017) "KARAKTERISASI PLASTIK BIODEGRADABEL DARI LDPE-gMA DAN PATI TANDAN KOSONG SAWIT", EKSAKTA: Berkala Ilmiah Bidang MIPA,18(02), pp. 30-38. doi: 10.24036/eksakta/vol18-iss02/48.

[126] Prihatini, R. (2017) "PEMANFAATAN AIR KELAPA UNTUK MENINGKATKAN PERTUMBUHAN AKAR STEK TUNASAKSILAR Andrographis paniculata Nees", EKSAKTA: Berkala Ilmiah Bidang MIPA, 18(02), pp. 62-68. doi: 10.24036/eksakta/vol18-iss02/54.

[127] Setianto, S. (2017) “ANALISA KUANTITATIF CAMPURAN SENYAWA OKSIDA SEBAGAI DASAR IDENTIFIKASI KANDUNGAN BAHAN SUMBER DAYA ALAM Studi Kasus : Kandungan Mineral pada Pasir Besi di Pesisir Pantai Selatan, Jawa Barat", EKSAKTA: Berkala Ilmiah Bidang MIPA, 18(02), pp. 173177. doi: 10.24036/eksakta/vol18-iss02/74.

[128] Prabowo, H. (2018) "Penyelidikan Kelayakan Kimia Dan Penyebaran Cadangan Pasir Besi Daerah Tiku Kabupaten Agam Untuk Bahan Baku Semen Pada Pt. Semen Padang”, EKSAKTA: Berkala Ilmiah Bidang MIPA, 19(1), pp. 39-42. doi: 10.24036/eksakta/vol19-iss1/121.

[129] Syafei, N. (2017) "Analisa Fenomena Korosi Pelat Pipa Baja Karbon Api 5l-X65 Dalam Larutan $250 \mathrm{Ml}$ Asam Asetat Dan $4750 \mathrm{Ml}$ Aquades Pada Kondisi Gas Co2 Dan H2s Jenuh Pada Suhu Ruang", EKSAKTA: BerkalaIlmiah Bidang MIPA, 18(02), pp. 113-120. doi: 10.24036/eksakta/vol18- iss02/63.

[130] Tutuarima, T. (2017) "SIFAT FISIK DAN KIMIA MARMALADE JERUK KALAMANSI (Citrus microcarpa) : KAJIAN KONSENTRASI PEKTIN DAN SUKROSA Physical and Chemical Properties of Marmalade Citrus of Calamondin (Citrus microcarpa) : Study of Pectin and Sucrose Concentrations", EKSAKTA: Berkala 
Ilmiah Bidang MIPA,18(02), pp. 164-172. doi: 10.24036/eksakta/vol18-iss02/73.

[131] Samah, S. (2017) "KARAKTERISASI PLASTIK BIODEGRADABEL DARI LDPE-G-MA DAN PATI TANDAN KOSONG SAWIT”, EKSAKTA: Berkala Ilmiah Bidang MIPA, 18(02), pp. 30-38. doi: 10.24036/eksakta/vol18- iss02/48.

[132] Suryelita, S., Etika, S. B. and Kurnia, N. S. (2017) "ISOLASI DANKARAKTERISASI SENYAWA STEROID DARI DAUN CEMARANATAL (Cupressus funebris Endl.)", EKSAKTA: Berkala Ilmiah Bidang MIPA, 18(01), pp. 86-94. doi: 10.24036/eksakta/vol18-iss01/23.

[133] Sudrajat, R. (2017) "Tinjauan Tentang Keterkaitan Parameter Dengan Model Regresi Multivariat Pada Kolam Ikan Tertutup", EKSAKTA: Berkala Ilmiah Bidang MIPA, 18(02), pp. 158-163. doi: 10.24036/eksakta/vol18- iss02/72.

[134] Ruswandi, R. (2018) "Determination of Fructose Content resulted by Inulin Hydrolysis with DNS as Oxidizer", EKSAKTA: Berkala Ilmiah Bidang MIPA, 19(1), pp. 14-23. doi: 10.24036/eksakta/vol19iss $1 / 102$.

[135] Setianto, S. (2017) "Analisa Kuantitatif Campuran Senyawa Oksida Sebagai Dasar Identifikasi Kandungan Bahan Sumber Daya Alam Studi Kasus : Kandungan Mineral pada Pasir Besi di Pesisir Pantai Selatan, Jawa Barat", EKSAKTA: Berkala Ilmiah Bidang MIPA, 18(02), pp. 173-177. doi: 10.24036/eksakta/vol18-iss02/74.

[136] Prihatini, R. (2017) "Pemanfaatan Air Kelapa Untuk Meningkatkan Pertumbuhan Akar Stek Tunas Aksilar Andrographis Paniculata Nees", EKSAKTA: Berkala Ilmiah Bidang MIPA, 18(02), pp. 62-68. doi: 10.24036/eksakta/vol18-iss02/54.

[137] Badrulfalah, B. (2018) "Sub Ruang Tutup Topologi Hasil Kali Ruang Metrik Kerucut", EKSAKTA: Berkala Ilmiah Bidang MIPA, 19(1), pp. 63-67. doi: 10.24036/eksakta/vol19 iss1/128.

[138] Rahmi H.G, I. (2017) “Telaah Faktor-Faktor Yang Mempengaruhi Status Gizi Balita Di Kota Padang Berdasarkan Berat Badan Per Tinggi Badan Menggunakan Metode Cart", EKSAKTA: Berkala Ilmiah Bidang MIPA, 18(02), pp. 86-99. doi: 10.24036/eksakta/vol18-iss02/59.

[139] Sumarmin, R. (2018) "Pengaruh Ekstrak Kulit Buah Manggis (Garcinia mangostana L.) terhadap Histologis Pankreas Mencit (Mus musculus L. Swiss Webster) yang Diinduksi Sukrosa”, EKSAKTA: Berkala Ilmiah Bidang MIPA, 19(1), pp. 100-112. doi: 10.24036/eksakta/vol19-iss1/123.

[140] Tutuarima, T. (2017) "SIFAT FISIK DAN KIMIA MARMALADE JERUK KALAMANSI (Citrus Microcarpa) : KAJIAN KONSENTRASI PEKTIN DAN SUKROSA Physical And Chemical Properties Of Marmalade Citrus Of Calamondin (Citrus Microcarpa) : Study Of 
Pectin And Sucrose Concentrations", EKSAKTA: Berkala Ilmiah Bidang MIPA, 18(02), pp.164-172. doi: 10.24036/eksakta/vol18iss02/73.

[141] Saiya, A. (2017) “Analisis Residu Klorpirifos Dalam Sayuran Kubis Dengan Metode Hplc Di Beberapa Pasar Tradisional Di Sulawesi Utara", EKSAKTA: Berkala Ilmiah Bidang MIPA, 18(02), pp. 77-85. doi: 10.24036/eksakta/vol18-iss02/57. [142] Amir, H., Akmam, A., Bavitra, B. and Azhari, M. (2017) "Penentuan Kedalaman Batuan Dasar Menggunakan Metode Geolistrik Tahanan Jenis Dengan Membandingkan Konfigurasi Dipole-Dipole Dan Wenner Di Bukit Apit Puhun Kecamatan Guguk Panjang Kota Bukittinggi", EKSAKTA: Berkala Ilmiah Bidang MIPA, 18(01), pp. 19-30. doi: 10.24036/eksakta/vol18-iss01/13.

[143] Horiza, H., Azhar, M. and Efendi, J. (2017) "Ekstraksi Dan Karakterisasi Inulin Dari Umbi Dahlia (Dahlia Sp.L) Segar Dan Disimpan”, EKSAKTA: Berkala Ilmiah Bidang MIPA, 18(01), pp. 3139. doi: 10.24036/eksakta/vol18-iss01/14.

[144] Ningsih, S. K. (2017) "Sintesis Dan Karakterisasi Nanopartikel Zno Doped Cu2+ Melalui Metoda Sol-Gel", EKSAKTA: Berkala Ilmiah Bidang MIPA, 18(02), pp. 39-51. doi: 10.24036/eksakta/vol18-iss02/51.

[145] Susilaningrum, D. (2017) "Pemodelan Regresi Logistik Pada Faktor Yang Mempengaruhi Phbs Pada Rumah Tangga Penderita Tbc Di Pesisir Surabaya", EKSAKTA: Berkala Ilmiah Bidang MIPA, 18(02), pp. 121-128. doi: 10.24036/eksakta/vol18-iss02/65.

[146] Putri, D., Fifendy, M. and putri, M. (2018) "Diversitas Bakteri Endofit Pada Daun Muda Dan Tua Tumbuhan Andaleh (Morus Macroura Miq.)”, EKSAKTA: Berkala Ilmiah Bidang MIPA, 19(1), pp. 125-130. doi: 10.24036/eksakta/vol19-iss1/122.

[147] Yanuar, F., Tillah, M. and Devianto, D. (2018) "Modeling Of Human Development Index Using Ridge Regression Method”, EKSAKTA: Berkala Ilmiah Bidang MIPA, 19(2), pp. 1-11. doi: 10.24036/eksakta/vol19-iss2/134.

[148] Hidayat, D. (2017) "Implementasi Pengontrol Pid Pada Model Fisis Elektronik", EKSAKTA: Berkala Ilmiah Bidang MIPA, 18(02), pp. 178-185. doi: 10.24036/eksakta/vol18-iss02/75.

[149] Susilaningrum, D. (2017) "Pemodelan Regresi Logistik Pada Faktor Yang Mempengaruhi Phbs Pada Rumah Tangga Penderita Tbc Di Pesisir Surabaya”, EKSAKTA: Berkala Ilmiah Bidang MIPA, 18(02), pp. 121-128.doi: 10.24036/eksakta/vol18-iss02/65.

[150] Horiza, H., Azhar, M. and Efendi, J. (2017) "Ekstraksi Dan Karakterisasi Inulin Dari Umbi Dahlia (Dahlia Sp.L) Segar Dan Disimpan", EKSAKTA: Berkala Ilmiah Bidang MIPA, 18(01), pp. 3139. doi: 10.24036/eksakta/vol18-iss01/14 